\title{
JUDGE CARDOZO IN THE COURT OF APPEALS
}

ON January first, I9I4, Judge Cardozo took his seat upon the bench of the Supreme Court of the State of New York. In the municipal election of November, rgr3, men opposed to the continued domination of the city government by the Democratic organization had nominated and elected a " fusion" ticket for city offices and for judicial positions within the city. There were three vacancies in the Supreme Court to be filled by election in New York County. For one of these vacancies Benjamin N. Cardozo was nominated. He was an independent Democrat deeply interested in government, but he had never taken an active part in politics. His name was almost unknown to " practical" politicians and to the general public. As a lawyer he had never appeared in any sensational cases; he was seldom mentioned in the newspapers; he had not been the confidential adviser of great corporations or of powerful financiers; he had neither taste nor talent for finding a way through the intricacies of corporate finance or the laws governing industrial promotions or mergers. He had, however, gained a high reputation among the members of the bench and bar as a deep student of the law, as a keen analyst of legal principles and judicial precedents, as an advocate with extraordinary powers of exposition and persuasion who never presented a contention to court or jury which he could not support with logical argument and with almost unrivaled learning. It has been said of him that he was a lawyers' lawyer and a judges' judge. Certainly his nomination and election as a judge were hailed by the members of the bench and bar, and bench and bar have accorded him in his judicial career a constantly increasing admiration and an affectionate respect for which I know no parallel.

Judge Cardozo served only one month as a judge of a court of first instance, and during that month he sat without a jury. I have been told that he conducted the trial of cases during that month with the skill of a master; but it would be idle to attempt 
any analysis of Judge Cardozo's work in the trial court or any estimate of the work he might have done if he had remained there longer. He tried no cases and rendered no judgments of general interest. As part of his judicial career this short period of trial work has no real significance. He sometimes regretted that he did not have longer experience in trial work. He believed that through such experience an appellate judge learns how to appraise the possible effect of errors committed during a trial; that only a judge who knows the atmosphere of a trial is fitted to determine whether error committed in its heat was prejudicial. Judge Cardozo's associates in the Court of Appeals always believed that his experience as trial counsel compensated for lack of experience as a trial judge.

Judge Cardozo's real judicial career began when he went to the Court of Appeals. At that time the court consisted of seven judges elected for a term of fourteen years, and in addition three judges of the Supreme Court designated by the Governor to sit as judges of the Court of Appeals until the number of cases upon its calendar should be reduced to two hundred. There was a vacancy among the designated judges that had to be filled by appointment of the Governor. Governors, in the past, had always selected judges of long experience with established judicial reputation. The claims of several judges to preferment were urged upon Governor Martin H. Glynn, but some of his close friends told him that Cardozo, though the newest judge, was especially well fitted for such work. He was assured that though other judges might be satisfactory appellate judges, and, perhaps, something more than that, Cardozo would be a great judge. Judge Cardozo quickly justified his selection. Governor Glynn, a few months before his death, told me that he felt more pride in his designation of Judge Cardozo than in any other act of his official career.

It is, I think, significant that Judge Cardozo's designation caused no resentment or criticism among the justices of the Supreme Court whose claims had been passed over in favor of the younger and inexperienced man. Judge Cardozo's spurs as an author, a legal scholar and a judge were yet to be won. He had, it is true, pub-

I3 COL.

YAIE 383

HARV. 365 
lished in I9O3 his work on the Jurisdiction of the Court of Appeals but otherwise he had written no important legal paper or book. As an advocate he had shown scholarship and acumen; but after an experience on the bench of more than thirty years I cannot close my eyes to the fact that the physical position of the bench may give to a judge looking down from it upon an advocate at the bar, a feeling of superiority not always justified by personal qualities. Sadly I must concede that it is not easy for any of us to admit, even to himself, that the advocate to whom he listens may be a greater lawyer than the judge who is addressed. So even though, in retrospect, it seems that all of us should have known in Igr4 that Judge Cardozo would be the greatest judge on the bench of the State, few, if any, of us did recognize it at that time. Probably the genuine satisfaction with which his seniors greeted Cardozo's designation was a tribute to his character and his personality at least as much as to his ability. He had lunched with his associates daily for a month. All had felt his charm, and all had felt his modesty and selflessness. Even those who were seeking the preferment which was accorded to him could harbor no jealousy or resentment when he himself so evidently disclaimed title to the position and never ceased to wonder why it was tendered to him.

The Court of Appeals had a high reputation and great influence even before Judge Cardozo joined it. Edgar M. Cullen, its chief judge when Cardozo came to Albany, was a sound lawyer and a man of marked force, ability and public spirit. Associated with him were judges who had the confidence of the bar of the state and of the general public. Those who knew Judge Cardozo believed that he would bring added strength to a court already strong; none, I think, foresaw that he would lead the court along new ways. Few lawyers or judges then recognized that a "Victorian era" or an "Edwardian era" had come to an end and a new era had already begun in which men would become more conscious, and more intolerant, of economic inequality and social injustice, and would demand that government should devise new remedies where the old were slow or ineffective. In a democracy the legislature will before long bow to demands, sufficiently in- 
sistent, even when unwise. A legislator is swayed, consciously and properly, by his social philosophy - indeed an intelligent electorate chooses its legislators because of their social philosophy. Though, in theory, a judge arrives at his conclusions by logical process regardless of his personal predilections or social philosophy, in practice, of course, he inevitably will be swayed by them unless he carefully guards himself against their influence. A court which clings to outworn precedents under changing conditions, which attempts to read permanently into the law any social philosophy, cannot be a great court even though composed of judges of learning, wisdom and public spirit. In the Supreme Court of the United States, Mr. Justice Holmes was writing with incisive force great opinions in which he pointed out that "due process of law" did not mean that legal principles, legal concepts or legal remedies must be unchanging though times change and men change with the times. Other judges might agree but were slower in recognizing or giving effect to change. So, not long before Judge Cardozo joined the Court of Appeals, it had declared that the principle, embodied in workmen's compensation laws, that an employer might be required to provide compensation to an employee for an injury suffered without fault of the employer, violated the constitutional requirement of "due process." 1 During the years that Judge Cardozo sat in the court, it never again rendered a judgment which in comparable degree ignores the effect of changing conditions and changing ideas.

Within less than ten years after Judge Cardozo joined the court, it had become known throughout the English-speaking world as a great, progressive court. Judge Cardozo's influence contributed mightily, but it would not be fair to the other judges who sat with him during those years if the credit were given to him alone. It is sometimes said that only a blindly reactionary court could have rendered the Ives decision. In truth, few of the judges who then sat in that court were either blind or reactionary. In industrial controversies they had vindicated rights of labor which less forward-looking courts had denied, and which, indeed, the courts of some other jurisdictions do not even now recognize. In contro-

1 Ives v. South Buffalo Ry., 20r N. Y. 27r, 94 N. E. 43 I (I9rI).

I5 COL.

YALE 385

HARV. 367 
versies between individuals they had not always permitted ancient precedents to dictate an unjust conclusion. They knew that the common law was plastic and at times they felt free to mold it in new form. None the less, like other judges of that day, and perhaps of this day, they had adopted the social philosophy of the classic liberals of the nineteenth century, and consciously or unconsciously they were swayed by that philosophy. The war and the problems created or emphasized by the war had not yet awakened men to the fact that they must reconstruct their ideas and devise new methods of meeting human needs which, if not new, were at least more urgent than in the past. So in the conferences of the court Judge Cardozo found associates who did not always cling obstinately to old ways, though before abandoning them they might ask to be shown a new and better way. No man of this generation could do that better than Judge Cardozo. Then, too, Judge Pound, Judge McLaughlin, Judge Crane and Judge Andrews soon joined the court and some of them had, like Judge Cardozo, recognized the need for new ways.

Long before I joined the Court of Appeals in r924, its reputation and influence were firmly established. Students of the law had read with glowing enthusiasm Judge Cardozo's great opinions and the series of lectures on The Nature of the Judicial Process delivered in I92 I before the Law School of Yale University. I shall not attempt in this paper to analyze the opinions of Judge Cardozo or to appraise the value of his work while a judge of the Court of Appeals. A student of the printed word can perhaps measure its value more accurately - certainly more objectively - than one who has joined in discussion of the legal problems and has heard the spoken word before it became fixed in unalterable form; but only those who have heard the words of a judge spoken in the conference room can say how great the influence of the spoken word may have been.

A group of judges of notable distinction was gathered around the conference table when I first saw it. Frank FI. Hiscock, the chief judge, presided there. His associates sitting about the table were, in the order of seniority, Cardozo, Pound, McLaughlin, Crane and Andrews. All of them had been elected to the Court of 
Appeals after long and distinguished service in the Supreme Court of the State. All were men of marked independence of thought, and their views on social and political problems varied widely. No man, however great, no judge, however learned, could dominate the discussions of that group, but in those discussions Judge Cardozo wielded a mighty influence.

Upon one matter, and only one matter, there was firm agreement among the members of the Court. Each judge was sure that all his associates were men of unquestionable sincerity and honesty of purpose and of great ability. The discussions might at times become warm, for until convinced, each judge tried hard to show his associates the error of their ways; but no discussion ever diminished the respect of each judge for his fellows. In such discussions Judge Cardozo found a very real satisfaction, I might almost say happiness.

His vast and varied store of learning, his unflagging industry and his command of the gentle art of persuasion all contributed to his influence in those conferences. But far ahead of them I place the integrity of his mind which constrained him always to be on guard against arguments which might conceal an appeal to personal likes or dislikes; his selflessness and his independence, always restrained by his respect for the opinions of others. I wish that I could enable others to see and hear Judge Cardozo at these conferences as I have seen and heard him; then they would understand, I think, why the Court of Appeals was a really great court while Judge Cardozo sat there, and why Judge Cardozo's influence there was so great. One of my associates in the Court has often told the story of his first conference as a member of the court, so I violate no confidence in repeating it. The new judge had been informed that he would be called upon to begin the discussion of a case which had been assigned to him. He prepared for that discussion with great care, and he stated his views with precision and supported them with a wealth of authority. Cardozo, then chief judge, took up the discussion. "I had," he said, " come to the opposite conclusion, but I have been much shaken by what Judge — has said; nevertheless, though now with some hesitation, I shall state the views which I had formed, for what-

I7 COL. 
ever they may be worth, so that in the discussion we may consider all sides of the case." In the words of the new judge, "Judge Cardozo then proceeded to state his own views with a force and persuasiveness that left me in no doubt that he was right, and all I could do was to bow my head and admit my error." At first the new judge believed that only Judge Cardozo's kindliness and courtesy constrained him to say that his views were "shaken" by what he had heard. I think I know Judge Cardozo better. I am confident that he spoke there with complete sincerity, for even though in the conference room he might state with compelling force the conclusions which he had accepted after a study of a case, these conclusions remained for him tentative until he had heard and weighed the views of his associates. He would look for lurking fallacies in his own reasoning and unsuspected strength in opposing views. He would be "shaken " by opposing argument until he had analyzed, weighed and rejected it.

Recognizing that every judge has prepossessions which may unconsciously dictate his conclusions, Judge Cardozo would search his mind and soul to assure himself that his conclusions rested upon a firm, unshifting foundation. In his lectures and addresses he has disclosed his method of approach to judicial problems, and in his opinions he has shown almost unfailing wisdom in applying the rules which he had laid down for himself. Other judges reading what Judge Cardozo wrote were constrained to give thought to matters where previously there had been blind acceptance. A1ways he sought to know his own mind and to trace the influences which might lead to one choice rather than another, to understand and to appraise the comparative value of conflicting considerations. The discussions in the conference room served to clarify these considerations both for himself and for the other judges.

I have said in a memorial address: "He knew that in the common law, custom and law are inextricably intertwined; that as customs inevitably change, so law must keep pace with these changes; just as the customs of today, new though they seem, are rooted in the customs of yesterday - for always there is a measure of continuity in the customs of a people, and change, there, is seldom, if ever dictated by arbitrary will - so the law as formulated by 
judges should have the same measure of continuity and the same capacity for change. A court in which Judge Cardozo sat was bound to share that knowledge. It was bound to recognize that a balance must be found which will permit progress, but progress along a road where the traditions and established principles of the common law will still serve as guide-posts.

"Those who sat with Judge Cardozo in the Court of Appeals will, I am sure, agree with me that Judge Cardozo made his greatest contribution to the development of the common law, not in his written words - though they will long be read — but in the words spoken in the conference room, heard by few and soon forgotten, yet forgotten only after they had clarified each problem and had served to guide a great court along the road to sound development of the common law. I cannot bring back the spoken word, but I can record here its enduring influence."

That is what I have tried to do in this short paper.

Irving Leliman.

ALBANY, N. Y.

I9 COL. 